\title{
The Ethics of Organ Farming
}

Osebor Ikechukwu MONDAYa

\begin{abstract}
Ethics is a branch of philosophy that deals with distinctions between right and wrong. The primary concern of ethics is morally correct or incorrect, while expressing a sense of duty and obligation. Ethics studies human activities, which organ farming is one. Organ farming is the scientific method of using animals, such as pig, as an incubator to cultivate healthy genetically human organs. The organ farming raises ethical issues such as humanization of animal, introduction/invasions of new diseases to the public, animal welfare and the moral implication of inducing pluripotent cells. Using the method of a philosophical analysis, this paper maintains that Ethics of organ farming is significant because it serve as a guiding-binding thread, which holds genetic creation of human organs. The paper concludes that adherence to "organ farming ethics" would help to avert organ shortages and address ethical issues generated by organ farming.
\end{abstract}

Keywords: Organ farming, ethics, organ shortages, animal welfare, Franken-science

\section{INTRODUCTION}

Organ transplantation is one of the achievements of medical science in the $21^{\text {st }}$ century. The rational for organ transplantation is treatment of patients suffering from organ failure (1). Organ transplantation is challenged with the widening gap between the demand and supply of human organs, and this has led to the organ crisis. To close the gap between the demand and supply of organs, cadaver organ donations are ethical response to the problem of organ shortages but it could not solve the long time problem for lack consent.

Organ farming is the genetic synthesis of human-animal stem cells to producing human identical organs, with no hyperacute rejections (2). Organ farming raises ethical issues such as humanization of animals, animal welfare and the spread of infectious disease and inducement of the pluripotent cells. First let us discuss organ farming.

\section{ORGAN FARMING}

The use of animals for organ farming is prompted by the innovations in the development of medicine. This can be traced to the works of Aristotle and his Hippocratic theorization about the closeness of human beings and the vertebrate animals (3).

Organ farming is the scientific method of using animals, such as pig as an incubator to cultivate healthy genetically human organs (2). Organ farming is the extraction of human pluripotent adult stem cells, and genetically implanting them into the host animal. "The genes for generating specific organs are disabled and human induced pluripotent stem cells (iPSCs) are injected into pigs and sheep embryos. Induced pluripotent stem cells are adult cells that have been genetically reprogrammed to an embryonic stem-cell-like state. Once reprogrammed, iPSCs can grow into different types of cells and tissues (4). For example, reprogrammed skin cells would be able to differentiate into liver cells or heart cells" (5).

What is the rationale for organ farming? Organ farming aims at creating human organs within animals. Human-animal chimera reduces the risk of organ rejection when implanted into a human being.

${ }^{\mathrm{a} D e p a r t m e n t ~ o f ~ A r t s ~ a n d ~ H u m a n i t i e s ~ D e l t a ~ S t a t e ~ P o l y t e c h n i c ~ O g w a s h i-U k u ~ P m B ~ 1030, ~ N i g e r i a ~} ₫$ osebordarry@yahoo.com

Gönderim Tarihi: $27.09 .2020 \bullet$ Kabul Tarihi: 03.12.2020 
Organ farming works using DNA editing technology called "Crispr". The Crispr helps to edit animal embryos and genetically grow or differentiate an embryo into different organs such as the pancreas. The edited embryos are injected with human stem cells (6). "The experiment of organ farming involves the fusing of human stem cells into a pig embryo and then allows these cells to gestate for up to four weeks in surrogate sows, the scientists are trying to grow organs from different genetic make ups called "chimeras" in order produce tissue which is sufficiently human for genetic match" (2).

\section{WHAT ARE THE ETHICAL ISSUES RAISED BY ORGAN FARMING PRACTICES?}

The organ farming raises important ethical issues. These ethical issues require a philosophical diagnosis to identify the best ethical approach to address them. In this paper we are concerned with the ethics of organ farming and ethical issues surrounding the practice. The ethical issues surrounding organ farming include;

1. The possible transmission or infection of zoonotic diseases and inducement of the pluripontent cells

2. Animal welfare

3. Humanization of animals

The question is, how can these ethical issues surrounding animal be addressed? When we talk or think about ethics (or morals), we think of rules, which distinguishes right and wrong, such as the Golden Rule ("Do unto others as you would have them do unto you"). A code of professional conduct like the Hippocratic oath ("First of all, do no harm"), is a religious creed like the Ten Commandments ("Thou Shalt not kill..."), or a wise aphorisms like the sayings of Confucius (7). Ethics is the study of "moral principles and why people make moral and immoral decisions. It focuses on how people ought to behave based on their moral compass or values, and society's shared values, laws, and traditions" (8). Ethics is a branch of philosophy that analyzes right or wrong of an action. It studies all aspect of human life, which organ farming is one (9).

Ethics of organ farming are guidelines governing the conduct of organ research. "Ethics" are norm of conduct, it distinguishes between acceptable and unacceptable behavior (7) The ethics of organ farming is an important strategy for health and wellness, social inclusion and a major strategy to providing sufficient organs for candidates on the waiting list.

\section{THE POSSIBLE TRANSMISSION OR INFECTION OF ZOONOTIC DISEASES AND INDUCEMENT OF THE PLURIPONTENT}

Organ farming could lead to the introduction of zoonotic disease such as the Covid 19. Ethics of care: Researchers shun lackadaisical errors and carelessness in the experimentation of animal for organ farming. Researchers should critically analyzing each project under investigation and be regulated by the ethics of organ farming to avoid the introduction of zoonotic disease into the human population and improper inducement of pluripotent cells. The improper inducement of pluripotent cells raises question about human dignity. For critics, the inducement of pluripotent cells would lead destruction of embrayos and manipulation of the genome. While we acknowledge that above assertions, we maintain that there are no empirical evidence to show that organ farming had spread zoonotic diseases nor led to improper inducement of the pluripotent cells. However, we maintain that organ farming is guided by the ethics of care, regulated by law to avoid intolerable practice among researchers.

Ethic of Care is a genuinely new approach to ethics or whether it is a re-articulation of ethics of organ farming; In the Ethic of Care, one seeks to develop a skill at giving care appropriately, all the while balancing the amount of care necessary to sustain oneself. Since there is a goal, to care and to be cared for, it might even be thought of as having a consequentialist appeal. However, "there is a current debate over whether the Ethic of Care is a genuinely new approach to ethics or whether it is a re-articulation of a virtue ethic; In the Ethic 
of Care, one seeks to develop a skill at giving care appropriately all the while balancing the amount of care necessary to sustain oneself" (10).

\section{ANIMAL WELFARE}

Organ farming should be carried out in such a way that injury and suffering to the animal subjects and human recipients be minimized. Organ farming could lead to abuse of animals if not regulated. In Tom Regan's, The Case for Animal Rights and Peter Singer's, The Animal Liberation Movement, both scholars advocated rights and equal treatment of animals. The animal rights liberationist seeks to change the cruel and brutal treatment of animals (11). From the utilitarian standpoint, animals for experimentation is necessary for the advancement of medical and public health. However, animal experimentation is extensively abused in the context of unnecessary experimentation of animals for egoistic reasons (12).

A reflection of the unnecessary experimentation of animals, we maintain that animals should be treated just like human being because there is no ontological division between human beings and non-humans species. The critical question is, can animals and human beings be treated equally, considering different level of consciousness among organisms?

Moral evaluation of organ farming is resting upon the capacity to identify the axiological state between human beings and others. Organ farming will benefit candidates on the waiting list, then it should be permitted to avert worsening the organ crisis.

\section{HUMANIZATION OF ANIMALS}

Organ farming is crucial for the treatment of organ failure and promises similar results for other medical conditions in the future (13). Experimenters of animal subjects have been accused of "Franken-science", now, the ethical concerns about the creation of talking animals should not be taken seriously, along with what one might call the "Frankenstein fear." Medical researchers that create 'humanized' animal would generates monsters (14). Humanization of animal boiled down to the morals of care. Researchers faces ambiguous analytic decision, the appropriate decision is guided by ethics to avoid "Franken-science." More importantly, researchers are encouraged to persist in their analytic skills and continue to critically examine objects under investigation for the common good of the society.

Organ farming is the incorporation of human cells or genetic information into animal models. The created organs has the potential to finding solution to the conditions currently threatening the existence of humankind (14). In this sense, organ farming ethics would be a watchdog to prevent "Frankenstein-like" experimentations in our society.

The ethics of organ farming are transcendental ethics. They are transcendental because it is founded on an objective moral order. A subjective moral order is not in place because it is not an invention of a single researcher, nor they are within the power of a single researcher to alter. Additionally, there may be a shift of paradigm to accommodate innovations or casuistry. Research innovations should be within the confines of the established ethics. Researchers are at liberty to contribute to the public discourse or health policy through the development of ethical casuistry but it should be within the framework of the established research ethics.

\section{CONCLUSION}

Ethics of organ farming are a set of rules or mode of conduct, which research is based. Organ farming is an essential contributor to a multitude of scientific advances this past century and will continues to aid human understanding for the treatment of organ failure. What appears from this paper is that organ farming is linked to moral issues. A refection of theses moral issues, we maintain that it is an emerging concept in the 
field of bioethics. We hope that this paper will open the entrance to scholars, who are curious about the moral dimensions of organ farming.

\section{REFERENCES}

1. Osebor I, Paul O. Distributive justice: A common good for altruistic organ donation. SriLankan Journal of Anaesthesiology. 2020 [cited 2020 August 14] 28(2):171-173. DOI: http:/doi.org/10.4038/slja.v28i2.8609

2. Osebor I. Is Organ Farming a Panacea to Organ Crisis? Ethical Implications. Journal of Asian and International Bioethics. 2018; 28 (5) p.104-108

3. Daryl MT. The Metaphysical Science of Aristotle's "Generation of Animals" and Its Feminist Critics. The Review of Metaphysics. 1992 [cited 2020 August 14] Vol. 46, No. 2 p. 307-341 https://www.jstor.

4. Ronald B. Is It Ethical to Grow Human Organs in Pigs? Newsweek magazine. 2016 [cited 2020 August 14]. https://www.newsweek.com/it-ethical-grow-human-organs-pigs-465326

5. Krista C. Rat-grown mouse pancreases help reverse diabetes in mice Stanford University School of Medicine, Stanford Health Care (formerly Stanford Hospital \& Clinics), and Communication \& Public Affairs. 2017 [cited 2020 Nov.14]. http://mednews.stanford.edu.

6. Clive C. Breakthrough over growing human organs in animals. Financial times February 18, 2018.

7. David B. What is Ethics in Research \& Why is it Important? 2015. [cited 2020 Nov. 14 ] https://www.niehs.nih. gov/research/resources/bioethics/whatis/index.cfm

8. Osebor IM. Ethics of Cognitive Restructuring: A Rehabilitation of Rape Victims And Offenders. Voices in Bioethics. 2020. [cited 2020 November 14] Vol.6 https://Doi.Org/10.7916/Vib.V6i.7223

9. Osebor IM. The Relevance of deep ecological principles in Aquatic Crisis: A philosophical Bangladesh Journal of Bioethics. 2020 [2020 Nov.14] 11 (2): 35-41. https://doi.org/10.3329/bioethics.v11i2.50392

10. Claudia C. Introduction to the Ethicof Care. [cited 2020 August 14] http://www.cabrillo.edu/ -cclose/docs/ Ethics\%20of\%20Care\%20Sp11.pdf

11. Emily W. Animal Liberation Movement and Animal Rights. 17, 2014. Available https://scholarblogs.emory.edu/ millsonph115/2014/11/17/animal-liberation-movement-and-animal-rights/

12. Mojca R. Medical Racism JAHR. 2020 [cited 2020 Nov 14] Vol. 11/1(21). https://doi.org/10.21860/j.11.1.1

13. Osebor IM., Stephen Chukwuma CC, and James JP. The Relevance of Joseph Fletcher's Situation Ethics for Animal Experimentation in Clinical Studies. Journal of Clinical and Medical Sciences. 2018 [cited 2020 August 14] (4) p.2. https://www.longdom.org/open-access/the-relevance-of-joseph-fletchers-situation-ethics-for-animalexperimentation-in-clinical-studies.pdf

14. Nick C. Ethical-Rules-Needed-To-Curb-Frankenstein-Like-Experiments-On-Animals. Science Correspondent. 2011 [cited 2020 August 14] https://www.telegraph.co.uk/news/science/science-news/8652093/Ethical-rulesneeded-to-curb-Frankenstein-like-experiments-on-animals.html 